\title{
Distribution, host range and detection of seed-borne yellow mosaic disease on yardlong beans (Vigna unguiculata subsp. sesquipedalis L.) in the special region of Yogyakarta, Indonesia
}

\author{
DEDI MULYADI, SRI SULANDARI", SEDYO HARTONO, SUSAMTO SOMOWIYARJO \\ Department of Plant Protection, Faculty of Agriculture, Universitas Gadjah Mada. Jl. Flora 1, Bulaksumur, Sleman 55281, Yogyakarta, Indonesia. \\ Tel./fax.: +62-274-563062, •email: sulandari77@ugm.ac.id
}

Manuscript received: 3 July 2021. Revision accepted: 27 August 2021.

\begin{abstract}
Mulyadi D, Sulandari S, Hartono S, Somowiyarjo S. 2021. Distribution, host range and detection of seed-borne yellow mosaic disease on yardlong beans (Vigna unguiculata subsp. sesquipedalis L.) in the special region of Yogyakarta, Indonesia. Biodiversitas 22: 3949-3957. Yellow mosaic disease found in legumes is caused by Mungbean yellow mosaic India virus (MYMIV). MYMIV has been reported to cause yellow mosaic infection on yardlong beans (Vigna unguiculata subsp. Sesquipedalis L.) in various regions of Indonesia and has resulted in major yield loss. Symptoms of mosaic and yellowing are found in the leaves and on the pods, which means that the virus may be seed-borne. The purpose of this study was to identify the distribution, host range of pathogens, and to investigate whether yellow mosaic virus was seed-borne or not. Sample collection, disease incidence and severity observations were done at yardlong bean fields in the District of Sleman, Bantul, and Kulon Progo. Samples were tested using PCR (Polymerase Chain Reaction) and phylogenetic tree analysis. Host range was tested by inoculating MYMIV using Bemisia tabaci to test plants. Two types of seeds were used in seed-borne tests, i.e. certified commercial seeds and malformed pods from infected plants. Results showed that yellow mosaic virus was found in all observation sites. Highest disease incidence was recorded in Sleman (50\%) followed by Kulon Progo (45\%) and Bantul (23\%). Whereas 45.89\%, 41.29\% and 39.83\%, disease severity was noted in Sleman, Kulon Progo and Bantul, respectively phylogenetic tree analysis showed that isolates used in this study were similar to other Indonesian isolates. Host range test revealed that yardlong beans, mungbeans (Vigna radiata L.), sesame seeds (Sesamum indicum L.), cucumber (Cucumis sativus L.), chili peppers (Capsicum annuum L.), eggplants (Solanum melongena L.), and tomatoes (Lycopersicum esculentum Mill.) were infected with MYMIV, showing symptoms of irregular yellow and mosaic spots on plant leaves. Transmission test exhibited that tobacco plant (Nicotiana tabacum L.) did not show viral infection. PCR detection proved that MYMIV isolates obtained from Yogyakarta may be transmitted through whole seeds, seed coat, cotyledon, and young leaves from sprouting seeds. Mild mosaic symptoms were appeared after sprouting, and gradually vein clearing was observed at 14 days, mosaic at 21 days, and complete leaf yellowing at 45 days after planting.
\end{abstract}

Keywords: Host range, Mungbean yellow mosaic India virus, seed-borne viruses, Vigna unguiculata

\section{INTRODUCTION}

Yardlong beans (Vigna unguiculata subsp. sesquipedalis $\mathrm{L}$.) is a popular vegetable in Indonesia and globally. Based on Indonesia's Central Bureau of Statistics in 2018 , the production of yardlong beans reached 370,225 ton/years and productivity of 6.93 ton/ha. The harvest of fresh products in Indonesia is still low and is hindered by yellow mosaic disease caused by Mungbean yellow mosaic India virus (MYMIV) which is transmitted by Bemisia tabaci (Nurulita et al. 2015). Yellow mosaic disease was first reported in India to infect lima beans (Phaseolus lunatus L.) in 1940 (Capoor and Varma, 1948). Yellow mosaic disease has been reported since 2008 on yardlong beans in Java, Indonesia (Damayanti et al. 2009). Yellow mosaic disease has been reported to cause $85 \%$ economic loss in mungbeans (Vigna radiata L.) in India (Karthikeyan et al. 2014), and $53.87 \%$ of yardlong beans in Indonesia (Purwaningsih et al. 2016). The infection of MYMIV resulted in special symptoms of leaf yellowing, yellow and green spots, and mosaics (Nurulita et al. 2015). Yellow irregular or green spots appear on young leaves and develop into a more conspicuous appearance on the leaves (Naimuddin et al. 2016). Infected plants produce less flowers and pods, pods are malformed, and if infections occurs three weeks after planting, yield loss may reach 100\% (Karthikeyan et al. 2014).

Yellow mosaic disease has a wide range of hosts and is able to infect legumes, including yardlong beans (Nurulita et al. 2015), soybean (Glycine max L.) (Sutrawati et al. 2020), mungbeans and black-eyed pea (Vigna unguiculata subsp. unguiculata) (Kumar et al. 2017). In Indonesia, mixed infections have been reported between Mungbean yellow mosaic virus (MYMV) with Tomato yellow leaf curl virus (TYLCV), Tomato leaf curl virus (ToLCV), and Pepper yellow leaf curl virus (PepYLCV) on yardlong beans (V.U. sesquipedalis) (Sidik et al. 2017), mixed infection between MYMV with PepYLCV have also been reported to infect eggplant (Solanum melongena L.), chili pepper (Capsicum annuиm L.), melon (Cucumis melo L.), and cucumber (Cucumis sativus L.) (Purwoko et al. 2015). This shows that yellow mosaic disease infects not only 
legumes but may also occur on other plant species as inoculum sources in the field. Besides having wide host ranges, yellow mosaic disease has also been reported to be seed-borne on mungbeans ( $V$. radiata) and be specifically detected from seed coat, cotyledon, and embryo (Kothandraman et al. 2015). Host range of this virus should be tested because farmers often do mixed cropping and crop rotation between yardlong beans with other crops that are host of B. tabaci. In addition, there have been several reports of mixed infections between MYMV and other Begomovirus in Indonesia.

Several reports of yellow mosaic symptoms on yardlong beans have been reported in Yogyakarta. Symptoms are often found during vegetative and generative stages, but symptoms may vary between crops. This study aimed to identify the cause of the disease, the distribution of yellow mosaic in Yogyakarta, the host range, and test seed-borne of yellow mosaic on yardlong bean seeds. Identification was done by visually observing symptoms and using PCR methods followed by phylogenetic analysis to determine the type of MYMIV.

\section{MATERIALS AND METHODS}

\section{Field observation and sample collection}

Sample collection was done from the District of Sleman, Bantul, and Kulon Progo, Yogyakarta, Indonesia
(Figure 1). The areas selected were vegetable planting regions in Yogyakarta.

Field observations were done by collecting plant samples and calculating disease incidence and severity. Plant samples collected were yardlong bean leaves that showed symptoms of yellowing, mosaics, yellow and green spots. Disease incidence was calculated using the following formula (Waller et al. 2002):

Disease Incidence $=\frac{\text { Number of infected plants }}{\text { plent population }} \times 100 \%$

Disease severity was observed at 3 points in each location using the following formula (Waller et al. 2002):

$$
\begin{aligned}
& \text { Disease Intensity }=\frac{\Sigma(n \times v)}{Z \times N} \times 100 \% \\
& \text { Where: } \\
& \mathrm{n} \quad: \text { number of leaves infected at a certain category } \\
& \mathrm{V} \quad \text { : category value } \\
& \mathrm{N} \quad \text { : number of leaves observed } \\
& \mathrm{Z} \quad \text { : highest value scale }
\end{aligned}
$$

Score of disease severity used in this study were: (0) no symptoms, (1) leaf vein clearing, yellow spot, (2) yellowing of leaf veins, yellowing on large portions of lamina (3) yellowing on most portion of lamina, and leaf mosaic, (4) almost whole leaves are yellow and leaf experience mosaic (Adilah and Hidayat 2014).
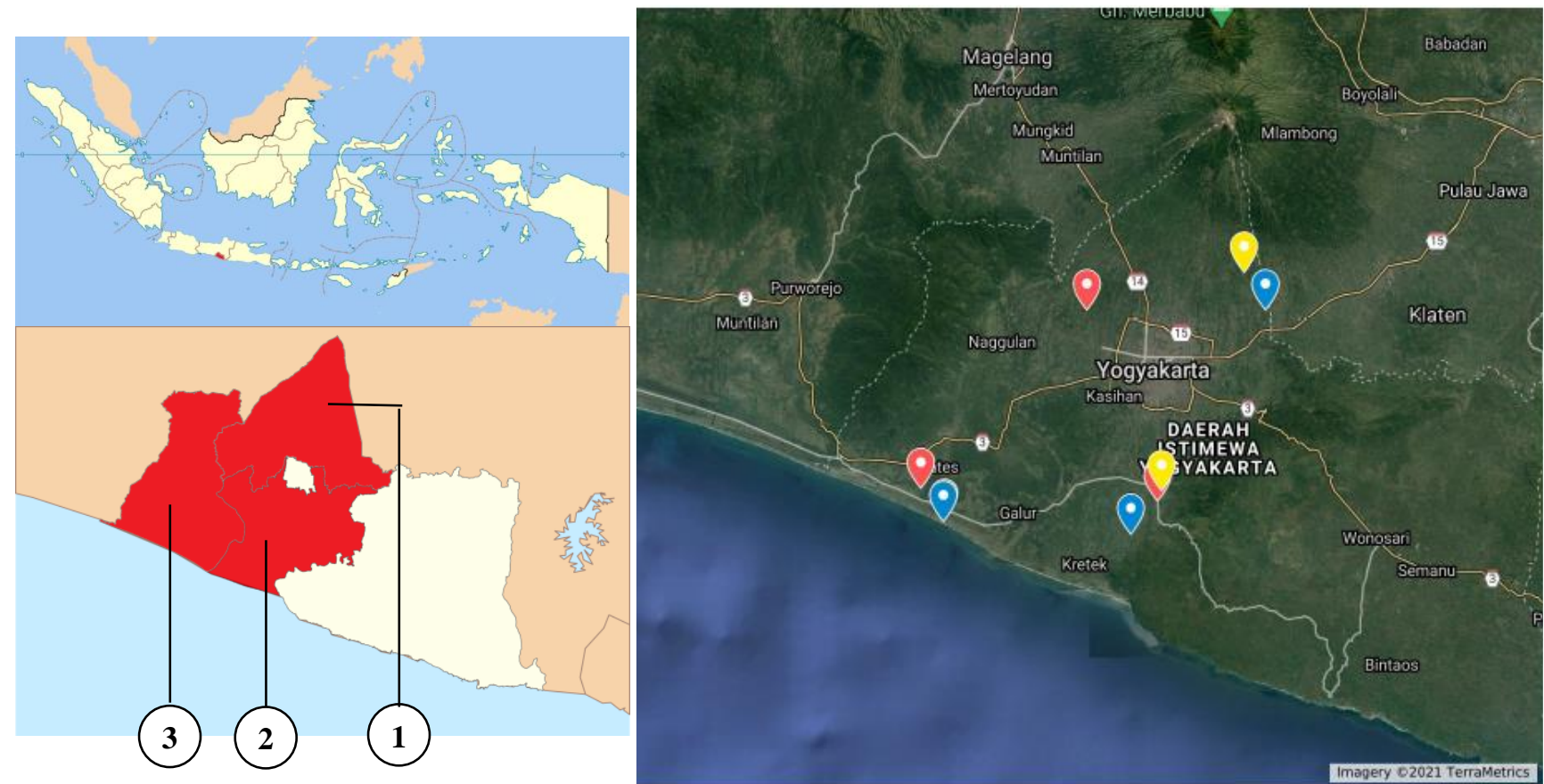

Figure 1. Location of sample collection in Yogyakarta Province, Indonesia: 1. Sleman, 2. Bantul, 3. Kulon Progo 


\section{Molecular detection}

Detection using PCR

Total DNA extraction from plants. As much as $0.1 \mathrm{~g}$ of fresh leaf samples from each location were extracted using a commercial kit from Genomic DNA Mini Kit for Plant (Geneaid, Taiwan). Extraction protocols were done using manual protocols. Total DNA was stored in $-20^{\circ} \mathrm{C}$ freezer and used as templates for PCR.

Total DNA extraction from insects. DNA was extracted from 3-4 B. tabaci using protocols of (Goodwin 1994). Total DNA was stored in $-20^{\circ} \mathrm{C}$ freezer and used as templates for PCR.

Sample detection and nucleotide sequencing

MYMIV was detected from plant and insect samples using the PCR method. The PCR reaction contained $5 \mu \mathrm{L}$ of Redmix Mastermix Taq Polymerase (Bioline, Germany), $0.5 \mu \mathrm{L}$ of primer forward, $0.5 \mu \mathrm{L}$ of primer reverse, $3 \mu \mathrm{L}$ of $\mathrm{ddH}_{2} \mathrm{O}$, and $1 \mu \mathrm{L}$ of DNA template. Amplification using AC2-F and AC2-R primer was done with 35 cycles consisting of predenaturation at $94^{\circ} \mathrm{C}$ (3 min), denaturation at $94^{\circ} \mathrm{C}(30 \mathrm{~s})$, annealing at $49^{\circ} \mathrm{C}(30 \mathrm{~s})$, extension at $72^{\circ} \mathrm{C}$ (1 $\mathrm{min})$, and final extension at $72^{\circ} \mathrm{C} \quad\left(\begin{array}{ll}10 & \mathrm{~min}\end{array}\right)$. Amplification using Krusty and Hommer primer consisted of 35 cycles of predenaturation at $95^{\circ} \mathrm{C}(1 \mathrm{~min})$, denaturation at $95^{\circ} \mathrm{C}(15 \mathrm{~s})$, annealing at $55^{\circ} \mathrm{C}(15 \mathrm{~s})$, extension at $72^{\circ} \mathrm{C}(10 \mathrm{~s})$, and final extension at $72^{\circ} \mathrm{C}(5$ $\mathrm{min})$. PCR product was visualized using agarose gel $(1 \%)$ and observed under a UV transilluminator. Nucleotide sequencing was done using a direct Sanger sequencing by PT Genetika Science Indonesia.

\section{Phylogenetic analysis}

Nucleotide sequence was analyzed using several programs, such as BLAST (http://blast.ncbi.nlm.nih.gov), Mega 7.0 (Kumar et al. 2016), and construction of phylogenetic tree using Maximum Likelihood with 1000 bootstrap.

\section{Host range test}

Host range test was done in a greenhouse belonging to Department of Plant Protection, Faculty of Agriculture, Gadjah Mada University. Host range test used an isolate from Sleman (Prambanan) as an inoculum source. Host range test was done in following steps:

\section{Test plant preparation}

Five healthy test plants were used such as yardlong beans (Vigna unguiculata subsp. sesquipedalis L.), mungbeans (Vigna radiata L.), sesame seed (Sesamum indicum L.), tobacco (Nicotiana tabacum L.), cucumber (Cucumis sativus L.), chili pepper (Capsicum annuum L.), eggplant (Solanum melongena L.), and tomato (Lycopersicum esculentum Mill.).

\section{Vector insect rearing}

B. tabaci was collected from yardlong bean plants using an aspirator and reared on healthy eggplants in insect cages. Before being used as vectors, insects were tested using PCR to ensure insects do not carry viruses (nonviruliferous).

\section{Inoculation}

The plant used as inoculum source was inserted into a cage (width $1.5 \mathrm{~m} \&$ height $2 \mathrm{~m}$ ). Non-viruliferous insect vectors were placed into cages for acquisition time of 24 hours. Insect vectors were then sampled, DNA extracted, and tested using PCR to ensure whether insect carried the virus (viruliferous) or not. Viruliferous insect vectors (80 insects $/ 5$ plants) were infested on test plants for 48 hours. After 48 hours, insects were mechanically controlled or sprayed using soap water.

\section{Observation}

The observation was done by observing the visible symptoms on test plants. Test plants were then tested using PCR method to ensure the presence of virus in plants.

\section{Seed borne test}

Seed-borne test was performed using the growing test method in greenhouse conditions free of insect vectors. Two types of seeds were used, namely commercially certified seeds (variety A: Hijau Star from Oriental Seed; variety B: KP1000 from Raja Seed) and malformed seeds from infected plants that showed yellow mosaic disease. The plants were observed from germination to maturity. PCR was confirmed to ensure virus existence in whole seeds, whole seeds from sprouting (germination of petri dish), seed coat, cotyledon, and young leaves from sprouting.

Table 1. Primers for amplification of yellow mosaic disease

\begin{tabular}{llll}
\hline Primers & Sequence & Target & References \\
\hline AC2-F & AGCTAATGACCCCTAAATTAT & $504 \mathrm{bp}$ & Roberts et al. (1984); Purwoko et al. (2015); \\
AC2-R & GAGTACTTGGATGAAGAGAAC & & Sidik et al. (2017) \\
Krusty & CCNMRDGGHTGTGARGGNCC & $580 \mathrm{bp}$ & Revill et al. (2003) \\
Hommer & SVDGCRTGVGTRCANGCCAT & & \\
\hline
\end{tabular}




\section{RESULTS AND DISCUSSION}

Distribution of yellow mosaic disease in Yogyakarta

Based on field observations, symptoms of yellow mosaic were found on yardlong bean fields in the District of Sleman, Bantul, and Kulon Progo. The symptoms observed among districts were similar, showing symptoms such as mosaics, yellow and green spots on leaves, yellowing of leaves, and yellowing on pods followed by malformation (Figure2). Disease incidence and severity were noted at each location. Disease severity increased as incidences were higher in the field (Table 2).

Infection of MYMIV caused mosaic symptoms on leaves, irregular yellow and green spots, bright yellow discoloration, and malformed leaves. In severe infection, leaves turn yellow and fall down. Infected plants produced fewer flowers and pods, pods contained smaller number of seeds and are also malformed (Deepa et al. 2019). The symptoms found at each location were similar. Yellow mosaic symptoms were frequently observed and newly grown diseased leaves showed prominent yellow discoloration, curling and malformation. Symptoms of yellow mosaic vary among host species and their susceptibility. According to Qazi et al. (2007), yellow mosaic symptoms begin with small yellow spots on the leaf veins and spread to leaf surfaces. In severe infection, all the leaves turn yellow.
Table 2. Disease incidence and severity percentage of yellow mosaic virus

\begin{tabular}{lcc}
\hline Sampling locations & $\begin{array}{c}\text { Disease incidence } \\
(\mathbf{\%})\end{array}$ & $\begin{array}{c}\text { Disease severity } \\
(\boldsymbol{\%})\end{array}$ \\
\hline Sleman & 50 & 45.89 \\
Bantul & 23 & 39.83 \\
Kulon Progo & 45 & 41.29 \\
\hline
\end{tabular}

The highest disease incidence was recorded in the Sleman District due to the customs of farmers planting yardlong beans with chili pepper in the same field or in fields surrounding yardlong beans. Chili pepper is the host of B. tabaci and is a vector of Begomovirus. This condition was different from the farmers of Kulon Progo, where disease incidences were also high, but due to farmers planting melon, chili, and eggplant which were host of $B$. tabaci. Mixed cropping with specific crops could affect disease incidence and severity. Yardlong bean intercropped with chili pepper in Sleman had higher disease incidence, the same pattern seen in Kulon Progo where melon, chili pepper, and eggplants were planted around yardlong bean fields that were the hosts of B. tabaci. Existing host plants of $B$. tabaci around yardlong bean fields have the potential to act as inoculum sources, allowing plant viruses to continually exist in the field.
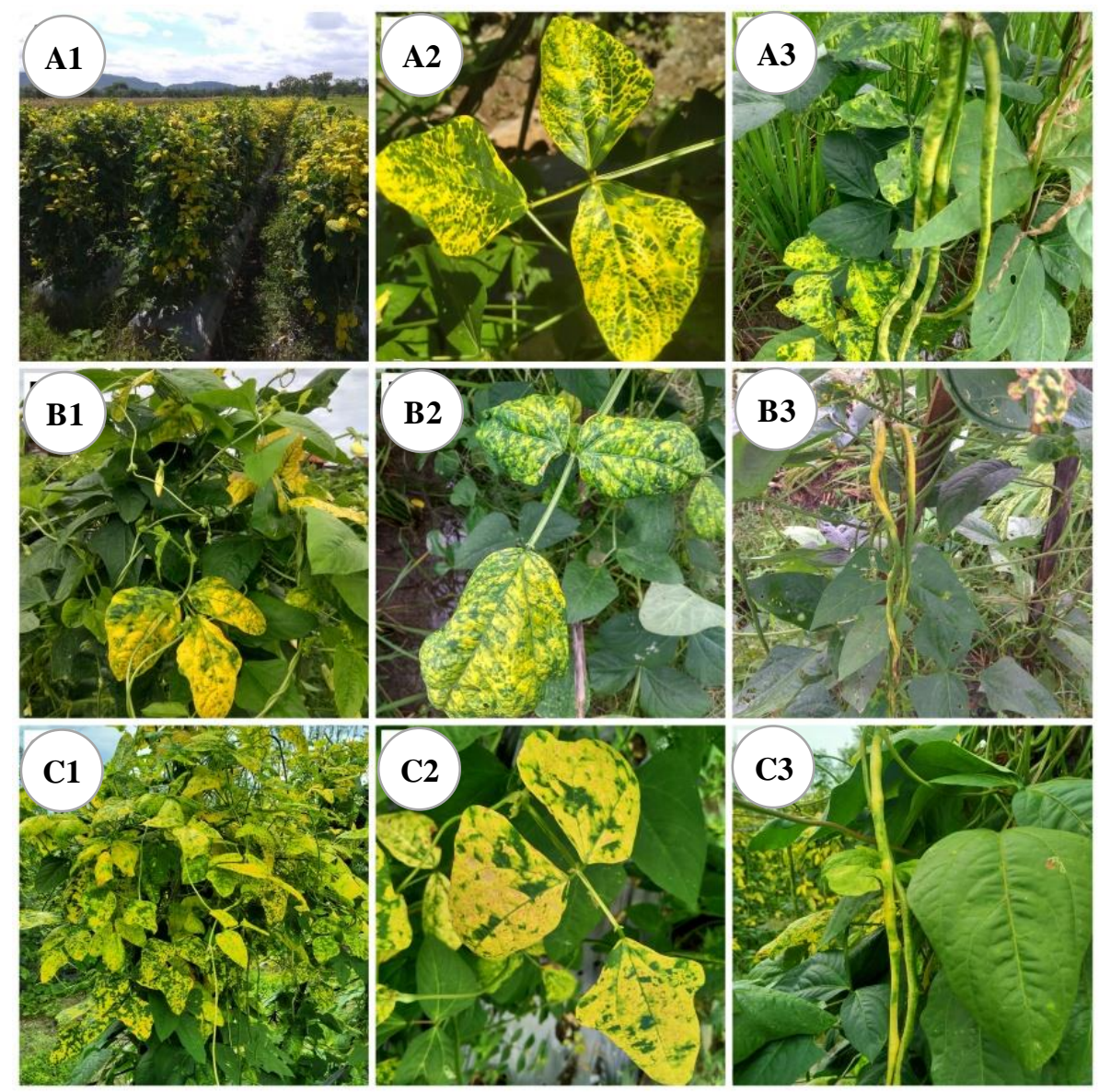

Figure 2. Symptoms of yellow mosaic disease in the field. (A1, A2, A3) Sleman, (B1, B2, B3) Bantul, (C1, C2, C3) Kulon Progo 
Brown et al. (2001) stated that mixed or overlapping crops can provide a continuous host for B. tabaci populations highly correlated with virus incidences. Planting patterns such as mixed cropping, and use of plastic mulch affect disease incidence. In Indonesia, farmers often do mixed cropping between two or more plant species within a field, with a high chance of increasing Begomovirus (Subiastuti et al. 2019). Plant disease epidemic is affected by hosts, pathogens, environment, human activities, and time. Besides those factors, epidemics by virus are affected by vectors, an organism that spread disease, causing vector population dynamics (Sudiono et al. 2005). Disease incidence in Bantul was only $23 \%$ because yardlong beans were not the main crop and were planted only for additional income. As side crops, yardlong beans in Bantul were planted on rice field ridges and rice was not host of $B$. tabaci. High disease incidence and severity affect the quality and quantity. High disease incidence can also affect growth and yield. Yellow mosaic can decrease yield on yardlong beans by up to $53.87 \%$ (Purwaningsih et al. 2016). Severely infected plants produced less and malformed pods. Pods showing mosaic symptoms were smaller malformed and usually sorted out because they did not meet consumer standards.

\section{Disease identification and phylogenetic analysis PCR detection}

All collection samples were successfully detected with specific primer (AC2-F and AC2-R), showing DNA band with the size of $504 \mathrm{bp}$ (Figure 3). These results proved that MYMIV caused yellow mosaic disease on yardlong beans in Yogyakarta.

\section{Phylogenetic analysis}

Besides field observations, molecular analysis was performed to identify the pathogen that infected yardlong beans in Yogyakarta. Nucleotide sequence of MYMIV isolates from Sleman (Seyegan), Sleman (Prambanan), Bantul dan Kulon Progo were processed using BLAST and MEGA 7.0. The MYMIV phylogenetic tree was constructed using the Maximum likelihood method at 1000 Bootstrap (Figure 4).

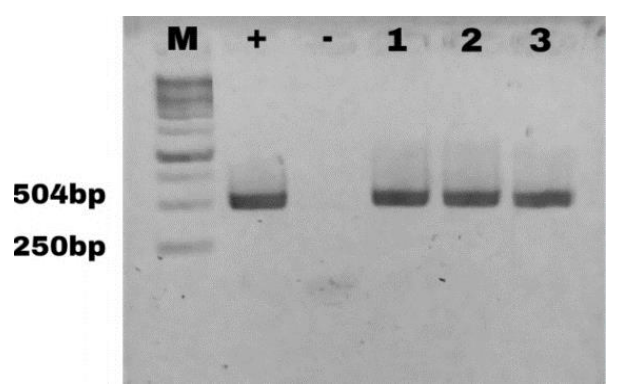

Figure 3. Amplification results of various isolates from Yogyakarta. M: Marker $1 \mathrm{~kb}$ DNA ladder, +: positive control, -: negative control, 1: Sleman isolate, 2: Bantul isolate, 3: Kulon Progo isolate

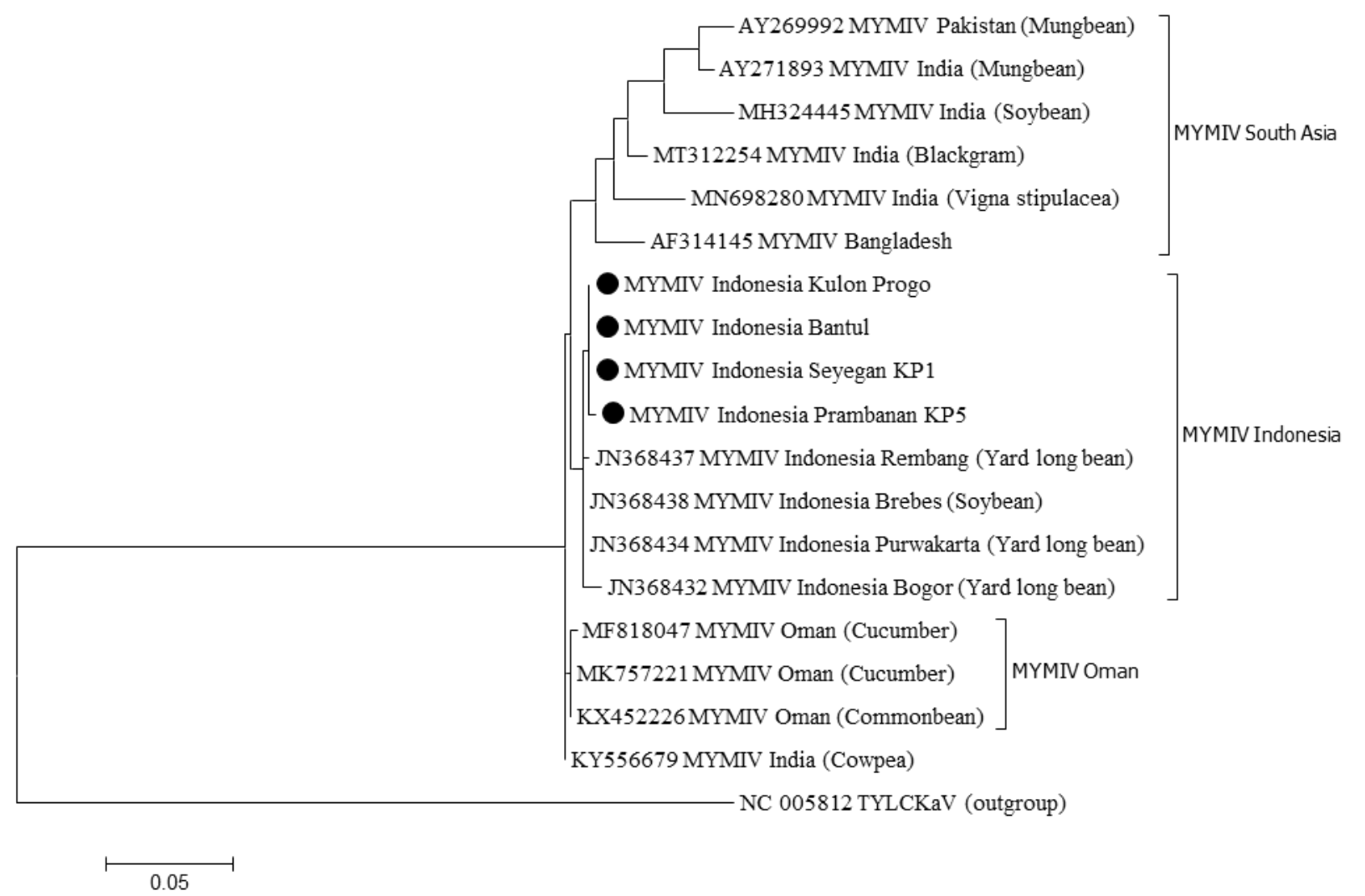

Figure 4. MYMIV phylogenetic tree of Sleman (Seyegan, Prambanan), Bantul, Kulon Progo and several isolates were taken from GenBank Database 
Phylogenetic tree analysis was separated into 3 groups, with the first group consisted of MYMIV isolates from South Asian countries (Pakistan, India, and Bangladesh), isolates used in this study (Kulon Progo, Bantul, Sleman \{Seyegan and Prambanan\}) were within the second group with other MYMIV isolates from Indonesia (Rembang, Brebes, Purwakarta, and Bogor), while the third group consisted of MYMIV isolates from Oman and India.

Based on the phylogenetic analysis, Indonesian isolates (Seyegan, Prambanan, Bantul, and Kulon Progo) were in the same group of other Indonesian isolates from Brebes, Purwakarta, Rembang and Bogor. This connection between MYMIV from various locations in Indonesia may be that these regions used the same commercial yardlong bean seeds. Besides being seed-borne from local commercial seed producers, MYMIV might enter Indonesia from imported seeds. This is based on Tsai et al. (2013) findings who found that Indonesia MYMIV from Brebes, Purwakarta, Rembang, and Bogor had a close relationship with isolates from India. It is important to investigate the possibility of MYMIV being introduced through seed imports, as healthy seeds are not a source of inoculum. Seed-borne tests may be useful for tracing the sources of this disease.

\section{Host range test}

The validation of non-viruliferous and viruliferous $B$. tabaci used in the test is shown in Figure 5. The host range test results are shown in Figure 6 and the validation results are shown in Figure 7.

Imagoes were used to transmit virus to various plant species tested in this study. Transmission results showed that test plants infected with MYMIV had yellow and mosaic symptoms on yardlong bean leaves and cucumber; irregular yellow spots on mungbeans, eggplants and tomato; yellowing symptoms on sesame seeds and chili pepper, while no symptoms appeared on tobacco (Figure 6).

Symptoms of yellow mosaic disease appeared on test plants 14-32 days after inoculation. The result of transmission was based on visual symptoms. Further PCR test was performed to prove that the mosaic and yellow symptoms in the tested plants were caused by MYMIV (Figure 7).

Based on visual observations and molecular detection, infection of yellow mosaic disease was found on all tested plants except tobacco. Yellowing and mosaic are typical symptoms of Begomovirus that infects legumes, produces yellow spots around leaf veins, and may reach $>70 \%$ in mature plants (Naimuddin et al. 2011).

Host range test also revealed that yellow mosaic disease could infect other plants than legumes, such as vegetable plants that may serve as alternative host of MYMIV in the field. Infection of MYMIV causes yellow and mosaic symptoms on leaves that decrease growth and plant yield. In addition, the B. tabaci population was always present in the field due to preferred host plants. As these major crops were often planted in monoculture and mixed cropping systems for a long period of time, the presence of this virus in these areas persists.

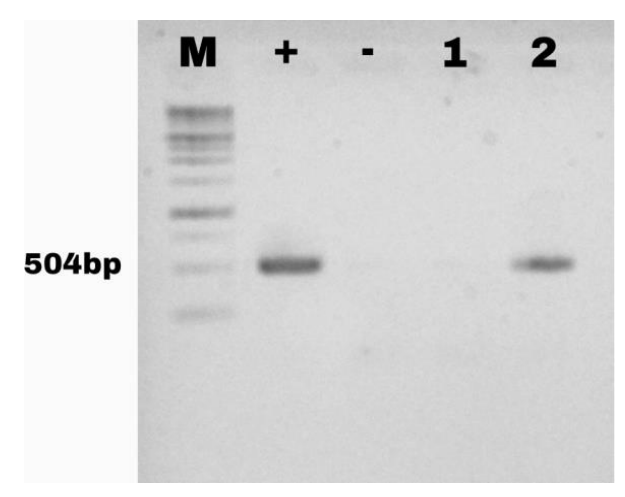

Figure 5. Amplification results of B. tabaci used as vector in the host range test. M: Marker $1 \mathrm{~kb}$ DNA ladder, +: positive control, : negative control, 1 . sterile vector (non-viruliferous), 2 . infective vector (viruliferous)

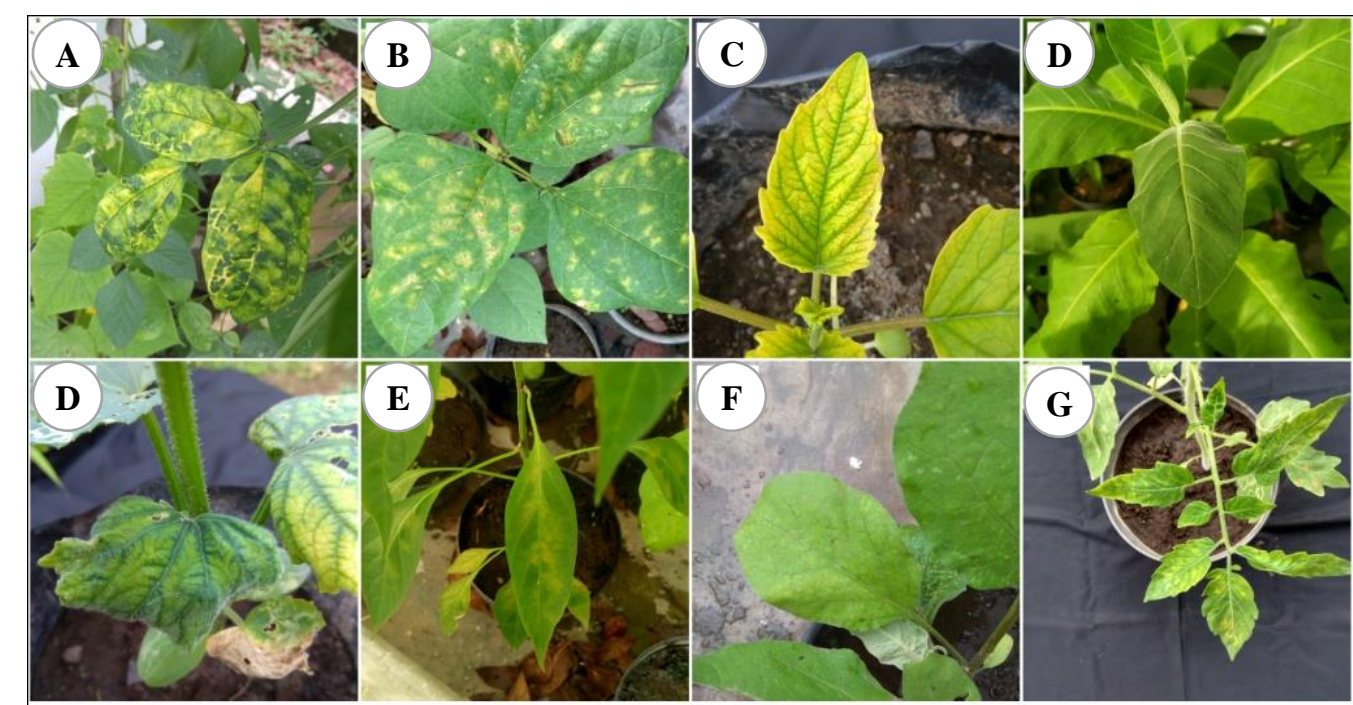

Figure 6. Morphological symptoms on host plants. A. Yardlong bean, B. Mungbean, C. Sesame, D. Tobacco, E. Cucumber, F. Chili Pepper, G. Eggplant, H. Tomato 


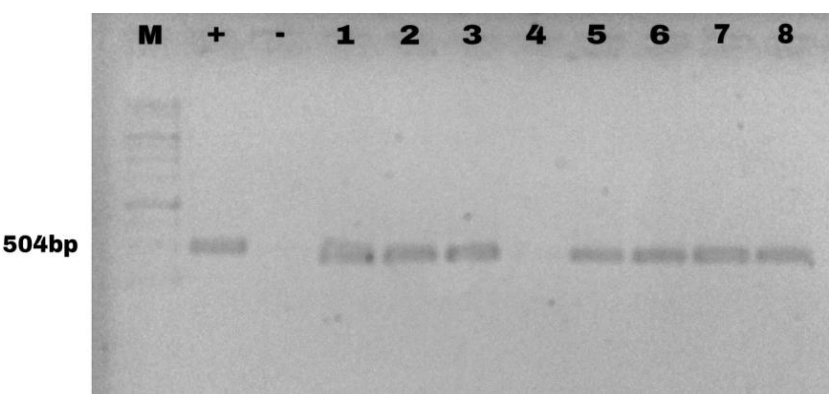

Figure 7. Amplification results from various tested host plants. M: Marker $1 \mathrm{~kb}$ DNA ladder, +: positive control, -: negative control, 1. yardlong bean, 2. mungbean, 3. sesame seed, 4. tobacco, 5. cucumber, 6. chili pepper, 7. eggplant, 8. tomato

\section{Seed-Borne test}

Tested seeds were taken from both certified commercial seed and malformed pods (Figure 8). Seeds were planted in cages and symptoms were observed every 2 days. Disease development of infected plants and seeds were compared to healthy plants from sprouting to mature plants (Figure 9 and 10).

Plants grown from infected seeds were showed vein clearing, mosaic symptoms, and later the entire leaves turned yellow. Yellow mosaic symptoms appear on the first leaf at the sprouting stage. The vein clearing symptoms and the dominant yellow mosaic symptoms were recorded at 14 DAP and 21 DAP, respectively at 45 DAP, leaf blades turn bright yellow (Figure 9). Plants grown from certified commercial seeds did not show any disease symptoms from sprouting to 45 DAP (Figure 10).

\section{PCR detection}

Certified commercial seeds and seeds obtained from malformed pods were tested using PCR method to determine whether MYMIV was seed-borne or not. Seed organs used in this study were whole seeds, seed coat, cotyledons, and young leaves. MYMIV was detected from whole seeds, seed coat, cotyledon and young leaves based on the appearances of DNA bands size $504 \mathrm{bp}$ (specific primer) (Figure 11) and 580 bp (universal primer) (Figure 12). MYMIV was not detected from whole seeds, cotyledon, and young leaves of certified commercial seeds, which means that seeds of variety A \& B did not infect with MYMIV (Figure 13).
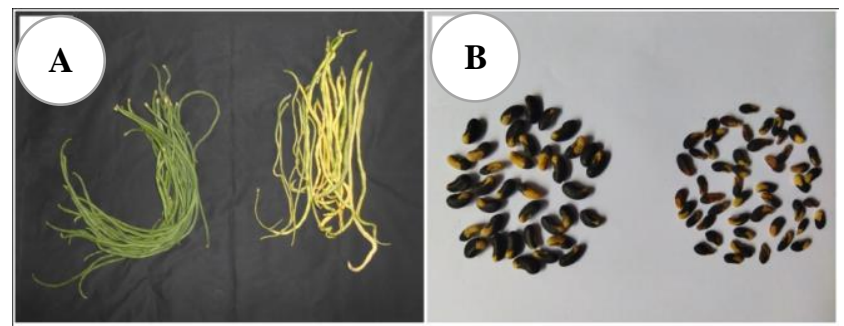

Figure 8. Comparison between healthy and yellow mosaic infected plants and seeds.
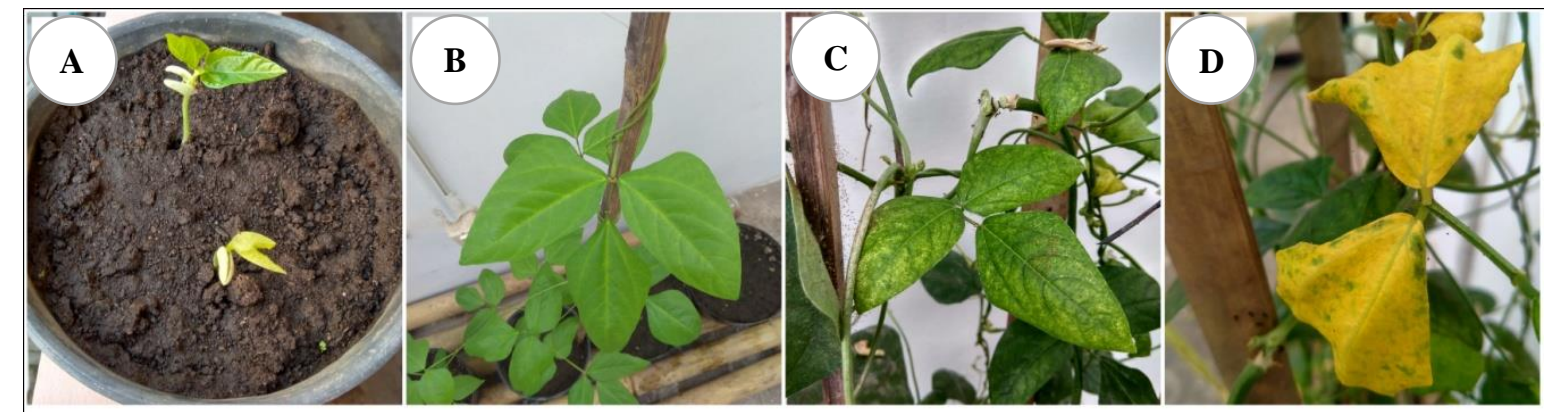

Figure 9. Development of yellow mosaic disease from seeds. A. Sprouting of infected seeds, B. infected leaves 14 days after planting, C. infected leaves 21 days after planting, D. infected leaves 45 days after planting
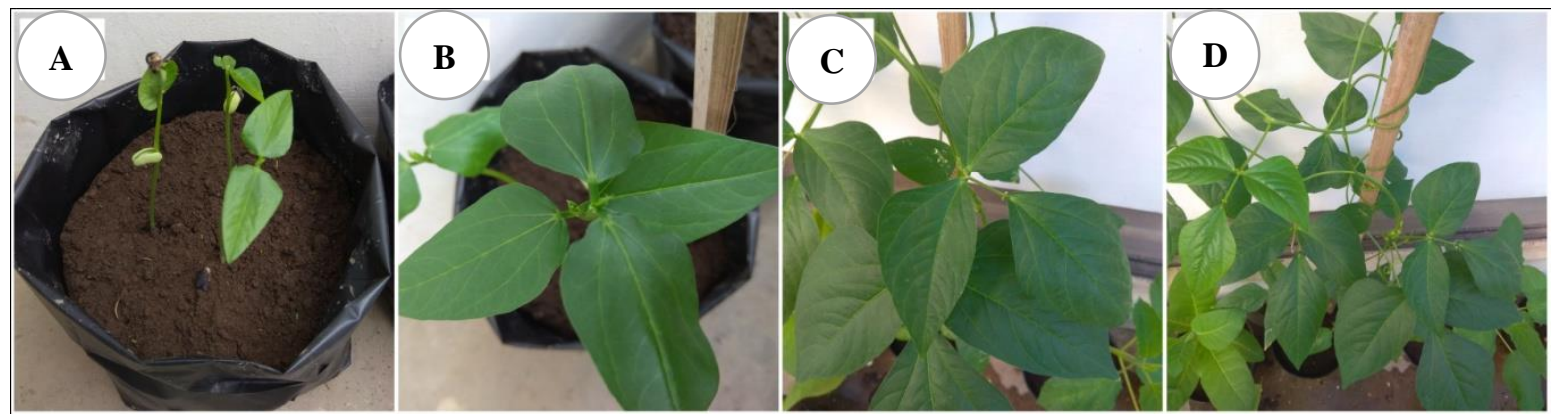

Figure 10. Development of healthy plants. A. Sprouting, B. 7 days after planting, C. 21days after planting, D. 45 days after planting 


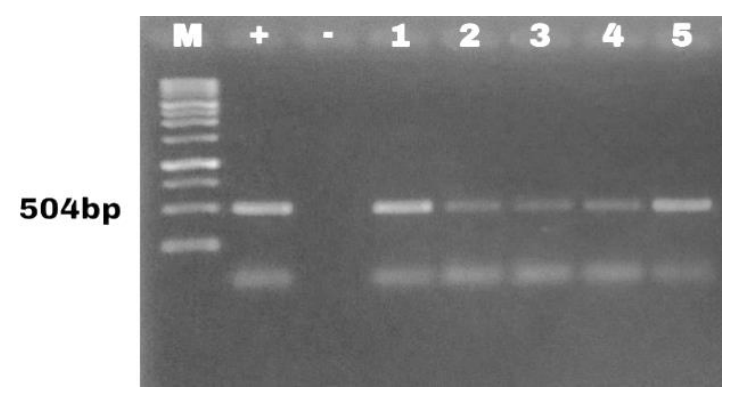

Figure 11. Amplification results from yellow mosaic infected seeds using specific primerAC2-F \& AC2-R. M: Marker $1 \mathrm{~kb}$ DNA ladder, +: positive control, -: negative control, 1. whole seeds, 2. seed coat, 3. cotyledon, 4. whole seeds (germination of petri dish), 5. young leaf

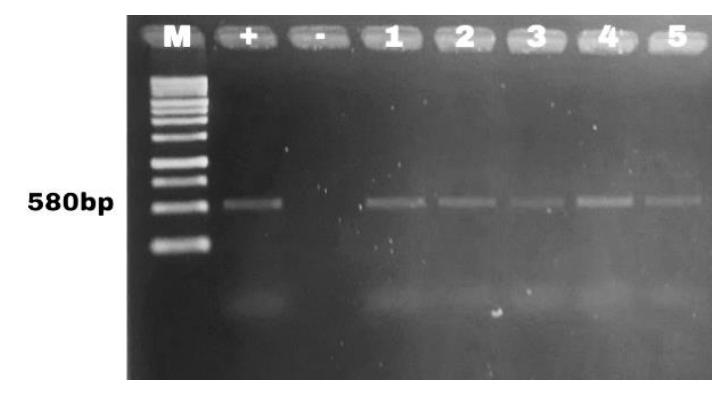

Figure 12. Amplification results of yellow mosaic infected seeds using a universal primer (Krusty and Hommer). M: Marker $1 \mathrm{~kb}$ DNA ladder, +: positive control, -: negative control, 1. whole seeds, 2. seed coat, 3. seed cotyledon, 4. whole seed (germination in petri dish), 5. young leaf.

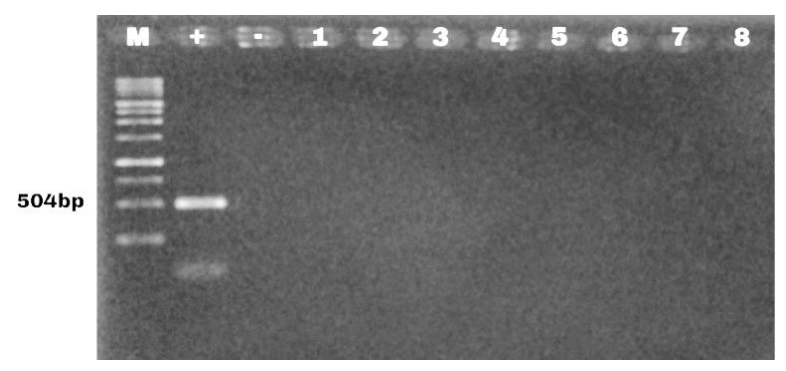

Figure 13. Amplification results from certified commercial seeds using specific primer for yellow mosaic disease. M: Marker $1 \mathrm{~kb}$ DNA ladder, +: positive control, -: negative control, 1. variety A whole seed, 2. variety A seed coat, 3. variety A young leaf, 4. variety A cotyledon, 5 . variety B whole seed, 6 . variety B seed coat, 7. variety B young leaf, 8 . variety B cotyledon

Infected seeds used for seed-borne tests were obtained from infected pods that showed yellow and mosaic symptoms. Malformed pods produce less and smaller seeds. Deepa et al. (2019) noted that infected plants produce less number of flowers, pods, discolored and malformed seeds.

Infected seeds and pods produced by plants show typical mosaic and yellow symptoms of MYMIV infection. Kothandraman (2015) reported that MYMV was seed- borne from mungbeans using PCR test. MYMV are localized in embryo axis (plumula, radicula, and hypocotil) based on observation using confocal microscope and electron microscope showed geminate particle.

Results showed that MYMIV was not detected in certified commercial seed. Commercial seeds are produced using standardized processes to ensure the seeds' quality by protecting plants and seed from pest and diseases (Minister of Agriculture, 2016). Various methods have been used to detect seed-borne pathogens, such as germination, serology, and molecular tests. PCR test are sensitive, specific, fast, and can be done on large scale (Bates and Taylor 2001). The use of healthy seeds in major crops is an effort to maintain quality and quantity of yield.

In conclusion, yellow mosaic disease was found in Yogyakarta which causes major loss in yield. The highest disease incidence was reported from Sleman (50\%) followed by Kulon Progo (45\%), and Bantul (23\%), while $45.89 \%, 41.29 \%$ and $39.83 \%$ disease severity was observed in Sleman, Kulon Progo and Bantul, respectively. MYMIV isolate Yogyakarta was found closely-related to other Indonesian isolates. The virus is seed-borne and it is reported for the first time in Indonesia. MYMIV isolate Yogyakarta has a wide host range in Leguminosae, Cucurbitaceae and Solanaceae.

\section{ACKNOWLEDGEMENTS}

The authors would like to thank the Begomovirus researcher group at sub-laboratory of Virology, Department of Plant Protection, Faculty of Agriculture, Gadjah Mada University, Indonesia for providing research materials.

\section{REFERENCES}

Adilah NF, Hidayat SH. 2014. Intensity of yellow leaf curl disease and population growth of whitefly on chili pepper genotypes. J Fitopatologi Indonesia 10 (6): 195-201. DOI: 10.14692/jfi.10.6.195.

Bates JA, Taylor EJA. 2001. Scorpion ARMS primers for SNP real-time PCR detection and quantification of Pyrenophora teres. Mol Pl Pathol 2 (5): 275-280. DOI: 10.1046/j.1464-6722.2001.00074.x.

Brown JK, Idris AM, Torres-Jerez I, Banks GK, Wyatt SD. 2001. The core region of the coat protein gene is highly useful for establishing the provisional identification and classification of Begomoviruses. Arch Virol 146: 1581-1598. DOI: 10.1007/s007050170080.

Capoor SP, Varma PM. 1948. Yellow mosaic of Phaseolus lunatus. Curr Sci 17: 152-153.

Damayanti TA, Alabi OJ, Naidu RA, Rauf A. 2009. Severe outbreak of a Yellow mosaic disease on the Yardlong bean in Bogor, West Java. Hayati J Biosci 16 (2): 78-82. DOI: 10.4308/hjb.16.2.78.

Deepa H, Govindappa MR, Naganur P, Shankarappa KS. 2019. Detection of Mungbean yellow mosaic virus in greengram through rolling circle amplification. J Exp Zool Ind 2 2(1): 425-428.

Goodwin PH, Xue BG, Kuske CR, Sears MK. 1994. Amplification of plasmid DNA to detect plant pathogenic mycoplasma-like organisms. Ann Appl Biol 124: 27-36. DOI: 10.1111/j.17447348.1994.tb04112.x.

Karthikeyan A, Shobhana VG, Sudha M, Raveendran M, Senthil N, Pandiyan M, Nagarajan P. 2014. Mungbean yellow mosaic virus (MYMV): a threat to green gram (Vigna radiata) production in Asia. Intl J Pest Manag 60(4): 314-324. DOI: 10.1080/09670874.2014.982230. 
Decree of the Minister of Agriculture of the Republic of Indonesia. 2016. Technical guidelines for certification of seeds for food crops No. 1316/HK.150/C/12/2016. http://bbp2tp.litbang.pertanian.go.id.

Kothandraman SV, Devadason A, Ganesan MV. 2015. Seed-borne nature of a begomovirus, mungbean yellow mosaic virus in black gram Appl Microbiol Biotechnol. DOI: 10.1007/s00253-015-7188-7.

Kumar S, Tanti B, Mukherjee SK, Sahoo L. 2017. Moleculer characterization and infectivity of Mungbean yellow mosaic India virus associated with yellow mosaic disease of cowpea and mungbean. Biocatal Agric Biotechnol 11: 183-191. DOI 10.1016/j.bcab.2017.07.004.

Kumar S, Stecher G, Tamura K. 2016. MEGA7: Molecular evolutionary genetics analysis version 7.0 for bigger datasets. Mol Biol Evol 33 (7): 1870-1874. DOI: 10.1093/molbev/msw054\%20.

Naimuddin K, Akram M, Sanjeev G. 2011. Identification of Mungbean yellow mosaic India virus infecting Vigna mungo var. silvestris L. Phytopathol Mediterr 50: 94-100. DOI: 10.14601/Phytopathol_Mediterr-8740.

Naimuddin K, Akram M, Singh NP. 2016. Yellow mosaic of mungbean and urdbean: current status and future strategies. J Food Legumes 29 (2): 77-93.

Nurulita S, Hidayat SH, Mutaqin KH, Thomas J. 2015. Molecular characterization of Begomovirus infecting Yardlong bean (Vigna unguiculata subsp. sesquipedalis L.) in Java, Indonesia. Biotropia 22 (1): 53-60. DOI: 10.11598/btb.2015.22.1.401.

Purwaningsih NNA, Puspawati NM, Nyana IDN. 2016. Influence mosaic disease and yellow to long bean (Vigna sinensis L.) production at Perean village, Baturiti, Tabanan. E-J Agroekoteknologi Tropika 5 (3): 212-221. [Indonesian]

Purwoko RR, Hartono S, Suputa, Lukman R, Wahyudin D. 2015 Emerging Pepper yellow leaf curl virus and Mungbean yellow mosaic virus of single Bemisia tabaci in Java, Indonesia. The $11^{\text {th }}$ International Student Conference at Ibaraki University, Ibaraki, Japan, December 5-6, 2015
Qazi J, Ilyas M, Mansoor S, Briddon RW. 2007. Legume yellow mosaic viruses: genetically isolated begomoviruses. Mol Pl Pathol 8 (4): 343348. DOI: 10.1111/J.1364-3703.2007.00402.X.

Revill PA, Ha CV, Porchun SC, Vu MT, Dale JL. 2003. The complete nucleotide sequence of two distinct geminiviruses infecting cucurbits in Vietnam. Arch Virol 148: 1523-1541. DOI: 10.1007/s00705-0030109-6.

Roberts IM, Robinson DJ, Harrison BD. 1984. Serological relationship and genome homologies among Geminiviruses. J Gen Virol 65: 17231730 .

Sidik EA, Hartono S, Sulandari S, Lukman R, Affifudin A, Wahyudin D, Santoso HB. 2017. Molecular evidence for mixed infection of four Begomoviruses in common bean and yard long bean showing severe yellow symptoms in East Java, Indonesia. In: Isnansetyo A, Nuringtyas TR (eds). Proceeding of the 1st International Conference on Tropical Agriculture. DOI: 10.1007/978-3-319-60363-6_7.

Subiastuti AS, Hartono S, Daryono BS. 2019. Detection and identification of Begomovirus infecting Cucurbitaceae and Solanaceae in Yogyakarta, Indonesia. Biodiversitas 20 (3): 738-744. DOI: 10.13057/biodiv/d200318.

Sudiono, Yasin N, Hidayat SH, Hidayat P, 2005. Penyebaran dan Deteksi Molekuler Virus Gemini Penyebab Penyakit Kuning pada Tanaman Cabai di Sumatera. J Hama Penyakit Tumbuhan Tropika 2: 113-121. DOI: 10.23960/j.hptt.25113-121.

Sutrawati M, Hidayat SH, Suastika G, Sukarno BPW, Nurmansyah A. 2020. Yellow mosaic disease on soybean. J Fitopatologi Indonesia 16 (1): 30-36. DOI: 10.14692/jfi.16.1.30-36.

Tsai WS, Shih SL, Rauf A, Safitri R, Hidayat N, Huyen BTT, Kenyon L. 2013. Genetic diversity of legume yellow mosaic Begomoviruses in Indonesia and Vietnam. Ann Appl Biol 163: 367-377. DOI: 10.1111/aab.12063.

Waller JM, Lenne JM, Waller SJ. 2002. Plant Pathologist's Pocketbook. $3^{\text {rd }}$ ed. CABI Publishing, New York. 